\title{
PENGGUNAAN GAMBAR LUAS DAERAH UNTUK MENINGKATKAN PEMAHAMAN SISWA SD TERHADAP OPERASI PENJUMLAHAN BILANGAN PECAHAN
}

\author{
ARSYAD \\ Guru SD Lingkup Dinas Pendidikan Kabupaten Bone \\ Email: arsyad@gmail.com
}

\begin{abstract}
Ide awal peneltian ini karena kurangnya pemahaman siswa terhadap penjumlahan pecahan khususnya siswa tidak mampu menjumlahkan pecahan dengan daerah luasan arsiran. Hal ini disebabkan oleh kurangnya pemahaman guru tentang pembelajaran penjumlahan pecahan dan strategi pembelajaran pada pecahan. Masalah penelitian ini adalah (1) bagaiman peningkatan pemahaman siswa dengan menggunakan gambar luas daerah di SD Negeri 60 Pongka. Tujuan penelitian ini adalah untuk meningkatkan pemahaman dalam menjumlahkan pecahan dengan menggunakan gambar luas daerah siswa kelas VI. Manfaat penelitian ini yaitu (1) memberikan pengalaman kemampuan secara langsung penerapan penggunaan gambar luas daerah dalam upaya meningkatkan kemampuan menjumlahkan pecahan (2) sebagai perbaikan mengajar pada pokok bahasan. Jenis penelitian ini adalah tindakan kelas yang berdaur ulang/siklus yaitu meliputi perencanaan, pelaksanaan, observasi, dan refleksi. Hasil penelitian ini yaitu pada siklus I (1) penajian pada tahap presentase dalam mempragakan gambar luas daerah belum maksimal (2) siswa mengalami kesulitan dalam menjumlahkan pecahan (3) kerja kelompok belum maksimal, sedangakan pada siklus II telah menunjuhkan peningkatan yang signifikan yaitu (1) penyajian pada tahap presentase dalam mempragakan gambar luas daerah telah maksimal berjalan sesuai dengan rencana (2) siswa merasa senang mengerjakan soal penjumlahan pecahan dengan menggunakan gambar luas daerah (3) siswa dapat menenyikan langka-langka penjulahan pecahan dengan menggunakan gambar luas daerah.
\end{abstract}

\section{PENDAHULUAN}

Matematika sebagai ilmu dasar sangat memegang peranan penting dalam pengembangan ilmu pengetahuan dan teknologi, misalnya dalam pengembangan ilmu ekonomi, biologi, kimia dan fisika memerlukan matematika. Karena peranan yang demikian itu maka seharusnya matematika dikuasai sedini mungkin oleh para siswa baik aspek terapannya maupun aspek penalarannya.

Ditinjau dari aspek terapannya matematika sebaiknya dalam pembelajaran di informasikan kepada siswa bahwa materi yang diajarkan dapat diterapkan pada bidang apa saja, utamanya yang berkaitan dengan kehidupan sehari-hari. Ditinjau dari aspek penalarannya juga diinformasikan kepada siswa bahwa matematika merupakan sarana untuk berfikir logis, analitis dan sistematis.

Dengan adanya kedua hal di atas siswa akan mengetahui manfaat praktis dari belajar matematika, khususnya pada operasi penjumlahan pecahan merupakan materi yang sangat esensial karena akan dipelajari dan digunakan dalam pelajaran matematika pada jenjang pendidikan berikutnya.

Dengan mengkonkretkan materi yang abstrak akan memberikan kesempatan bagi siswa untuk dapat mengembangkan kemampuannya dalam menciptakan suasana belajar yang kondusif, dan guru dapat menerapkan pembelajaran matematika yang sesuai dengan 
materi yang disajikan, sebagaimana pendapat J. Piaget (Muhsetyo, 2005: 19) menyatakan bahwa anak-anak usia sekolah dasar $7-12$ tahun masih berada dalam tahap operasional konkret.

Untuk menciptakan pemahaman siswa, pengkonkretan obyek-obyek yang akan dipelajari akan membentuk pemahaman yang bermakna pada diri dan dapat meningkatkan siswa. Matematika sebagai ilmu dan struktur dalam hubungannya dengan simbol-simbol yang diperlukan. Simbol-simbol itu sangat penting untuk membantu memanipulasi aturanaturan operasi yang ditetapkan, dan simbolsimbol juga dapat menjamin adanya komunikasi dan mampu memberikan keterangan untuk membentuk suatu konsep baru (Hudoyo, 1990: 5). Selama ini pembelajaran matematika masih mengikuti kebiasaan dengan urutan materi-materi pelajaran seperti: (1) diajarkan teori/defenisi/teorema, (2) diberikan contohcontoh, (3) diberikan latihan-latihan soal. Soedjadi (Ingana, 2003: 3).

Dalam pembelajaran seperti ini guru aktif menerangkan sedangkan siswa mengikuti apa yang disampaikan oleh guru. Skem (Ingana, 2003: 53 ) menyatakan bahwa pemahaman yang diperoleh siswa bersifat instrumental yaitu siswa dapat menggunakan rumus-rumus atau aturan-aturan untuk menyelesaikan soalsoal tetapi tidak memahami dan mengetahui makna dari apa yang dipelajari, sehingga sering meresahkan bahwa pengetahuan yang diperoleh siswa cepat dilupakan dan tidak mempunyai makna dalam kehidupanya.

Berdasarkan hasil observasi di SD Negeri 60 Pongka diperoleh informasi dari guru bahwa masih banyak materi matematika di sekolah dasar belum dikuasai siswa salah satunya adalah bilangan pecahan dan operasinya. Berdasarkan hasil observasi peneliti terhadap guru di SD Negeri 60 Pongka terindikasi bahwa mereka telah mengajar dengan baik namun siswa belum juga menguasai sepenuhnya, ini disebabkan karena guru mengajar tidak menggunakan benda konkret, guru berangapan bahwa menggunakan alat peraga hanya memakan waktu yang lama sehingga waktu mengajar yang direncanakan tidak di laksanakan dengan efisien keadaan seperti ini membuat siswa tidak maksimal menyerap pelajaran yang disajikan oleh guru, sehinggga siswa tidak memahami pembelajaran khususnya operasi penjumlahan bilangan pecahan, guru hanya memberikan penjelasan-penjelasan materi yang berupa penjelasan dan pemberian soal-soal latihan, tanpa mengkonkretkan bilangan-bilangan pecahan yang diajarkan.

Pembelajaran seperti ini siswa hanya mendengarkan penjelasan dari guru, hanya mengikuti apa yang disampaikan sehingga tidak memberikan pemahaman terhadap siswa, akibatnya siswa mudah melupakan apa yang telah di sampaikan oleh guru, yang menyebabkan siswa tidak memahami penjumlahan pecahan. Masih banyak ditemukan siswa yang menjumlahkan penyebut yang tidak sama. Siswa terkesan dengan bilangan pecahan yang berpenyebut sama sehingga ketika menemukan bilangan pecahan yang penyebutnya tidak sama maka mereka menjumlahkannya seperti pada pecahan yang sama penyebutnya.

Pemberian konsep terhadap siswa terkait dengan penjumlahan pecahan sangat lemah. Hal ini karena tidak adanya media yang digunakan oleh guru untuk membangkitkan skema siswa terhadap apa yang tengah dipelajari. Guru tidak dapat memberikan konsep tentang tata cara penjumlahan pecahan yang berpenyebut sama dan pecahan yang berpenyebut tidak sama. Indikasi seperti ini memberikan kesan bahwa guru belum memberikan sistem pembelajaran yang maksimal kepada siswa sehingga skema siswa selalu monoton

Bilangan pecahan dan operasinya mulai diajarkan sejak kelas VI sekolah dasar, yaitu dengan memperkenalkan konsep pecahan, pecahan senilai, membandingkan pecahan dan operasi penjumlahan bilangan pecahan yang sederhana. Materi pecahan ini dipelajari kembali dan dikembangkan di kelas $\mathrm{V}$ dan kelas VI sekolah dasar. 
Untuk mengajarkan operasi hitung bilangan pecahan di sekolah dasar, utamanya di kelas VI diperlukan suatu alat peraga yang tepat. Karena berkaitan dengan penanaman konsep dasar. Salah satu teknik yang dapat digunakan adalah dengan menggunakan alat peraga media gambar (persegi, persegi panjang, segi tiga, dan lingkaran) agar dapat meningkatkan meningkatkan kemampuan siswa terhadap operasi penjumlahan bilangan pecahan. Melalui alat peraga dapat dijelaskan konsep pecahan, pecahan senilai, membandingkan pecahan dan operasi bilangan pecahan secara nyata.

Pengajaran dengan menggunakan alat peraga akan memberikan hasil belajar siswa lebih cepat, lebih meningkat, dan lebih menarik Livie \& Livie (Arsyad, 2004: 9) mengatakan bahwa belajar melalui stimulus gambar dan stimulus visual membuahkan hasil belajar yang lebih baik seperti mengingat, mengenali, mengingat kembali dan menghubunghubungkan fakta dan konsep. Perbandingan pemerolehan hasil belajar melalui indera pandang dan indera dengar sangat menonjol perbedaannya. Kurang lebih $90 \%$ hasil belajar seseorang diperoleh melalui indera pandang dan hanya sekotar $5 \%$ diperoleh melalui indera dengar, kemudian $5 \%$ lagi dengan indera lainnya, Achsin, (Arsyad, 2004:10)Dari penjelasan di atas tampak bahwa pembelajaran dengan menggunakan alat peraga (luas daerah bangun persegi, persegi panjang, segitiga, dan lingkaran) menguatkan pemahaman siswa kelas VI SD Negeri 60 Pongka terhadap permasalahan operasi penjumlahan bilangan pecahan dan dapat meningkatkan kreativitas siswa dalam menyelesaikan suatu permasalahan yang ada dalam operasi penjumlahan pecahan.

Untuk memecahkan permasalahan di atas dilakukan dengan tindakan-tindakan sesuai merencenakan tiga tahap tindakan yaitu: (a) penanaman konsep pecahan dengan menggunakan gambar luas daerah, pada tahap ini di perlihatkan gambar-gambar bangun datar persegi, persegi panjang, segi tiga dan lingkaran. Kemudian penulis menjelaskan bahwa apa bila bangun-bangun tersebut dibagi sama besar maka hasilnya adalah seperdua, begitupun menjelaskan bilangan pecahan yang lain, (b) pecahan senilai dengan menggunakan luas daerah, pada tahap ini juga siswa dijelaskan pulah bahwa bilangan pecahan senilai merupakan bilangan yang sama nilainya bila dibagidengan menampilkan gambar luas daerah, (c) penjumlahan dengan menggunakan gambar luas daerah, penjumlahan pecahan merupakan menjumlahkan bagian-bagian dari satu kesatuan yang utuh dibagi sama besar dengan menampilkan gambar luas daerah serta menjelaskanya. Selanjutnya diakhiri dengan melakukan evaluasi untuk mengetahui kemajuan pelaksanaan tindakan.

Dari langkah-langkah pembelajaran di atas pembelajaran yang menggunakan gambar luas daerah menjadi salah satu alternatif yang tepat untuk meningkatkan kemampuan siswa, maka untuk meningkatkan pemahaman siswa terhadap operasi penjumlahan bilangan pecahan digunakan gambar luas daerah. sehingga tertanam konsep pecahan pada siswa dan dapat menigkatkan pemahaman siswa tentang penjumlahan pecahan. Hal ini sejalan dengan Aksin (Ashar, 2004: 4) bahwa 90\% pemerolehan hasil belajar siswa diperoleh dari indra pandang, 5\% dari indra dengar dan 5\% dari indera yang lain.

Dari sekian faktor-faktor penyebab materi tidak dikuasai siswa, dalam penelitian ini, penulis hanya meneliti satu faktor yaitu yang berkaitan dengan penggunaan alat peraga yang digunakan guru dalam mengajarkan matematika. Berdasarkan pada uraian pada latar belakang di atas, penulis melakukan suatu penelitian tindakan dengan judul "Penggunaan Gambar Luas Daerah untuk Meningkatkan Pemahaman Siswa Terhadap Operasi Penjumlahan Bilangan Pecahan di Kelas VI SD Negeri 60 Pongka Kabupaten Bone. 


\section{METODE PENELITIAN}

\section{A. Jenis dan Model Penelitian}

Penelitian ini adalah Penelitian Tindakan Kelas (PTK) karakteristik yang khas dari penelitian ini yakni tindakan-tindakan (aksi) yang berulang-ulang untuk memperbaiki proses belajar mengajar di kelas. Model tindakan yang dilakukan dalam penelitian ini sesuai dengan pendapat Kemmis dan Mc Taggart (Latri, 2003: 21) yang menyatakan bahwa proses penelitian tindakan merupakan sebuah siklus atau proses daur ulang yang terdiri dari empat aspek fundamental diawali dari aspek mengembangkan perencanaan kemudian melakukan tindakan sesuai dengan rencana, observasi/pengamatan terhadap tindakan, dan diakhiri dengan melakukan refleksi. Kegiatan penelitian ditempuh dalam suatu tahapan sehingga pemahaman siswa terhadap penggunaan luas gambar luas daerah dalam menjumlahkan pecahan diharapkan dapat tercapai secara maksimal.

\section{B. Setting Penelitian}

Yang menjadi subyek penelitian adalah siswa SD Negeri 60 Pongka yang aktif dan terdaftar pada semester genap tahun ajaran 2017/2018 dengan sasaran utama meningkatkan kemampuan siswa memahami konsep operasi penjumalah bilangan pecahan melalui penggunaan gambar luas daerah.

Memilih siswa kelas VI sebagai subyek penelitian karena (1) masih ditemui siswa mengalami kesulitan dalam operasi penjumlahan bilangan pecahan, (2) di sekolah ini belum dilakukan penelitian yang menggunakan gambar luas daerah dalam penjumlahan pecahan, (3) adanya dukungan dari kepala sekolah dan guru terhadap pelakanaan penelitian ini

\section{Faktor yang Diselidiki}

Untuk mejawab permasalahan di atas, ada beberapa faktor yang akan diselidiki, yaitu :

1. Faktor Siswa, yaitu dengan melihat apakah tingkat kemampuan siswa pada pokok bahasan penjumlahan pecahan dalam kategori rendah, sedang atau tinggi.

2. Faktor guru yaitu dengan memperhatikan bagaimana persiapan materi dan kesesuaian pendekatan pembelajaran yang digunakan dalam pembelajaran penjumalahan pecahan.

3. Faktor sumber belajar yaitu dengan memperhatikan sumber belajar yang digunakan apakah sesuai dengan tujuan yang hendak dicapai, demikian pula latihan-latihan yang diberikan, apakah sudah berjenjang sesuai dengan tingkat kemampuan siswa serta dengan tujuan yang akan dicapai sesuai dengan tahapan penggunaan gambar luas daerah sebagai media pembelajaran.

\section{Kehadiran Peneliti}

Sesuai dengan jenis penelitian yang telah dikemukakan sebelumnya, mka kehadiran peneliti di lapangan sangat diperlukan. Dalam penelitian ini peneliti berfungsi sebagai instrument kunci dan pemberi tindakan. Sebagai intrumen kunci, artinya peneliti sebagai pengamat, dan pewawancara. Sebagai pengamat, peneliti mengamati aktivitas siswa selama berlangsungnya kegiatan pembelajaran. Sebagai pewawancara, peneliti mewawancarai subyek penelitian berdasarkan jawaban yang telah diberikan pada setiap tes atau tugas yang telah dikerjakan. Dalam kedudukannya sebagai pemberi tindakan, peneliti bertindak sebagai pengajar yang membuat rancangan pembelajaran dan sekaligus sebagai penyaji bahan ajar selam berlangsungnya kegiatan penelitian. Di samping itu peneliti juga sebagai pengumpul data dan penganalisis data serta sebagai pelopor hasil penelitian. Dalam kegiatan pengamatan dan pengumpulan data, peneliti dibantu oleh guru kelas dan teman sejawat.

\section{E. Tehnik Penelitian}

1. Data dan Sumber Data

a) Data

Penelitian ini berupa hasil pekerjaan siswa terhadap soal yang diberikan yang meliputi (1) tes awal sebelum tindakan, (2) hasil wawancara dengan subyek penelitian, (3) hasil pengamatan selama pembelajaran berlangsung, (4) hasil catatan lapangan tentang kegiatan pembelajaran yang berkitan dengan tindakan. 
b) Sumber data

Sumber data penelitian ini adalah seluru siswa kelas VI SD Negeri 60 Pongka berdasarkan hasil tes awal yang telah di berikan.

2. Teknik pengumpulan data

Untuk pengumpulan Data dalam penelitian ini di lakukan dengan tes, wawancara, pengamatan, dan catatan lapangan. Empat teknik tersebut diuraikan sebagai berikut:

a) Tes

Tes dilakukan untuk mengmpulkan informasi tentang pemahaman siswa konsep penjumlahan pecahan. Tes di laksanakan pada awal penelitian, pada akhir setiap tindakan, dan pada akhir setelah diberikan serangkaian tindakan.

b) Wawancara

Wawancara dimaksudkan untuk manggali kesulitan siswa dalam memahami konsep penjumlahan pecahan, yang mungkin sulit di peroleh dari hasil pekerjaan siswa maupun melalui pengamatan.

c) Pengamatan

Pengamatan dilaksanakan oleh orang yang terlibat aktif dalam pelaksanaan tindakan yaitu guru yang mengajar di kelas VI dan teman sejawat. Pada pengamaatan ini di gunakan pedoman pengamatan untuk mencatat hal-hal yang di anggap penting

d) Catatan Lapangan

Catatan lapangan memuat hal-hal penting yang terjadi selama pembelajaran berlangsung yang dapat digunakan untuk melengkapi data yang tidak terekam dalam lembar observasi.

\section{F. Analasis Data}

Analisis data dalam penelitian ini dilakukan selama dan sesuda pengumpulan data. Analisis data dilakukan dengan membandingkan hasil pengamatan, Wawancara, Catatan lapangan dengan indikator-indikator pada tahap refleksi dari data penelitian. Data yang terkumpul dianalisis dengan menggunakan analisis kualitatif yang dikembangkan oleh Miles dan Huberman (1992:18) yang terdiri dari tiga tahap kegiatan yang dilakukan secara berurutan, yaitu: (1) mereduksi data, (2) menyajikan data, (3) menarik kesimpulan, (4) vertifikasi data.

\section{G. Pengecekan Keabsahan Data}

Untuk mengecek keabsahan data digunakan teknik triangulasi dan teknik diskusi sengan teman sejawat. Menurut Moleong (1998:178) triangulasi dalah teknik pengecekan keabsahan datayang mwlibatkan sesuatu yang lain di luar data itu untuk keperluan pengecekan atau sebagai pembanding terhadap data itu.

Ada dua teknik triangulasi yang dilakukan dalam penelitian ini, triangulasi dengan metode dan triangulasi dengan sumber. Triangulasi dengan metode dilakukan dengan cara membandingkan dan mengecek balik sesutu informasi yang diproleh melalui observasi, wawancara, catatan lapangan, dan tes akhir tindakan. Triangulasi dengan sumber dilakukan dengan cara membandingkan data hasil observasi teman sejawat dan observasi peneliti dengan hasil wawancara.

Diskusi dengan teman sejawat dan guru sebagai pengamat dalam penelitan ini dimaksudkan untuk membicarakan proses dan hasil penelitian kemudian merencanakan tindakan selanjutnya.

\section{H. Prosedur Penelitian}

Dalam penelitian ini, penulis terlebih dahulu melakukan tes awal berupa tes diagnostic untuk mengetahui kemampuan awal siswa, sebelum diberikan tindakan. Selain tes awal, penulis juga melakukan observasi awal untuk mengetahui ketetapan tindakan yang akan diberika dalam rangka meningkatkan hasil belajar matematika khususnya penjumlahan pecahan.

Dari hasil evaluasi dan observasi awal,maka dalam refleksi ditetapkan tindakan yang digunakan untuk menungkatkan hasil belajar matematika siswa, yaitu melalui pembelajaran dengan menggunakan gambar luas daerah sebagai media pembelajaran.

Berdasarkan refleksi awal tersebut maka penelitian tindakan kelas ini dilaksanakan dengan prosedur sebagai berikut :

a) Perencanaan 
Kegiatan yang dilakukan dalam tahap perencanaan ini meliputi :

1 Membuat scenario pembelajaran dalam melaksanakan tindakan

2 Membuat lembar observasi untuk melihat bagaimana suasan belajar mengajar di kelas saat penggunaan gamabr luas daerah diaksanakan

3 Membuat kusioner untuk mengumpulkan data tentang tanggapan siswa mengenai pelaksanan metode penggunaan gambar luas daerah dalam pembelajaran.

4 Membuat alat bantu mengajar yang diperlukan dalam rangka membantu siswa memahami konsep-konsep matematika khususnya operasi penjumlahan pecahan dengan baik.

5 Mendesain alat evaluasi untuk meningkatkan pemahaman siswa terhadap materi penjumalahan pecahan.

b) Pelaksanan Tindakan

Tindakan penelitian ini dilakukan menurut model yang dikemukakan oleh Kemmis dan Mc Taggart (Latri, 2003: 21) yang meliputi kegiatan perencanaan, pelasksnan tindakan, observasi dan refleksi. Tindakan yang telah dirancang dan dilaksanakan oleh penulis berkolaborasi dengan teman sejawat dan guru kelas VI SD Negeri 60 Pongka. Pembelajaran yang dilakukan penulis dengan menggunakan gambar luas daerah sebagai media pembelajaran dengan skenario pembelajaran yang telah dibuat.

Kriteri keberhasilan untuk tindakan, apabila siswa telah memahami konsep operasi penjumalahan bilangan pecahan dengan menggunakan gambar luas daerah sebagai media pembelajaran.

c) Observasi

Observasi dilaksanakan dengan menggunakan lembar observasi yang telah dibuat. Proses observasi dilakukan oleh penulis untuk mengamati guru dalam kelas selama melaksanakan tindakan dalam proses pembelajaran dengan menggunakan gambar luas daerah sebagai media, pengamatan juga dilakukan terhadap prilaku dan aktivitas siswa selama proses pembelajaran berlangsung dan dampak yang ditimbulkan dari prilaku guru terhadap siswa selama proses pembalajaran.

d) Refleksi

Refleksi dilaksanakan pada akhir siklus pelaksanaan tindakan, refleksi tersebut ditujukan untuk memenuhi ada atau tidak adanya peningkatan hasil belajar matematika pada pokok bahasan yang diajarkan. Alat evaluasi yang digunakan adalah tes hasil belajar yang disusun penulis. Apabila secara klasikal siswa telah memperoleh nilai 6,5 paling rendah maka tindakan dianggap telah berhasil dilaksanakan. Dan apa bila nilai yang diperoleh siswa belum mencapai standar yang diharapkan maka dilanjutkan pada tahap siklus berikutnya, Dengan melihat kelemahan-kelemahan pada pembelajaran sebelumnya seperti

1) Data situasi pelaksanaan gambar luas daerah dengan menggunakan lembar observasi

2) Data tanggapan siswa terhadap pelaksanaan penggunaan gambar luas daerah dengan menggunakan kuisioner.

3) Data refleksi diri serta perubahanperubahan yang terjadi dalam kelas, diambil dengan menggunakan jurnal

4) Data tentang hasil belajar penjumlahan pecahan diambil dengan menggunakan tes hasil belajar

Adapun skema alur siklus yang direncanakan dalam peneltian ini disajikan sebagai berikut: 


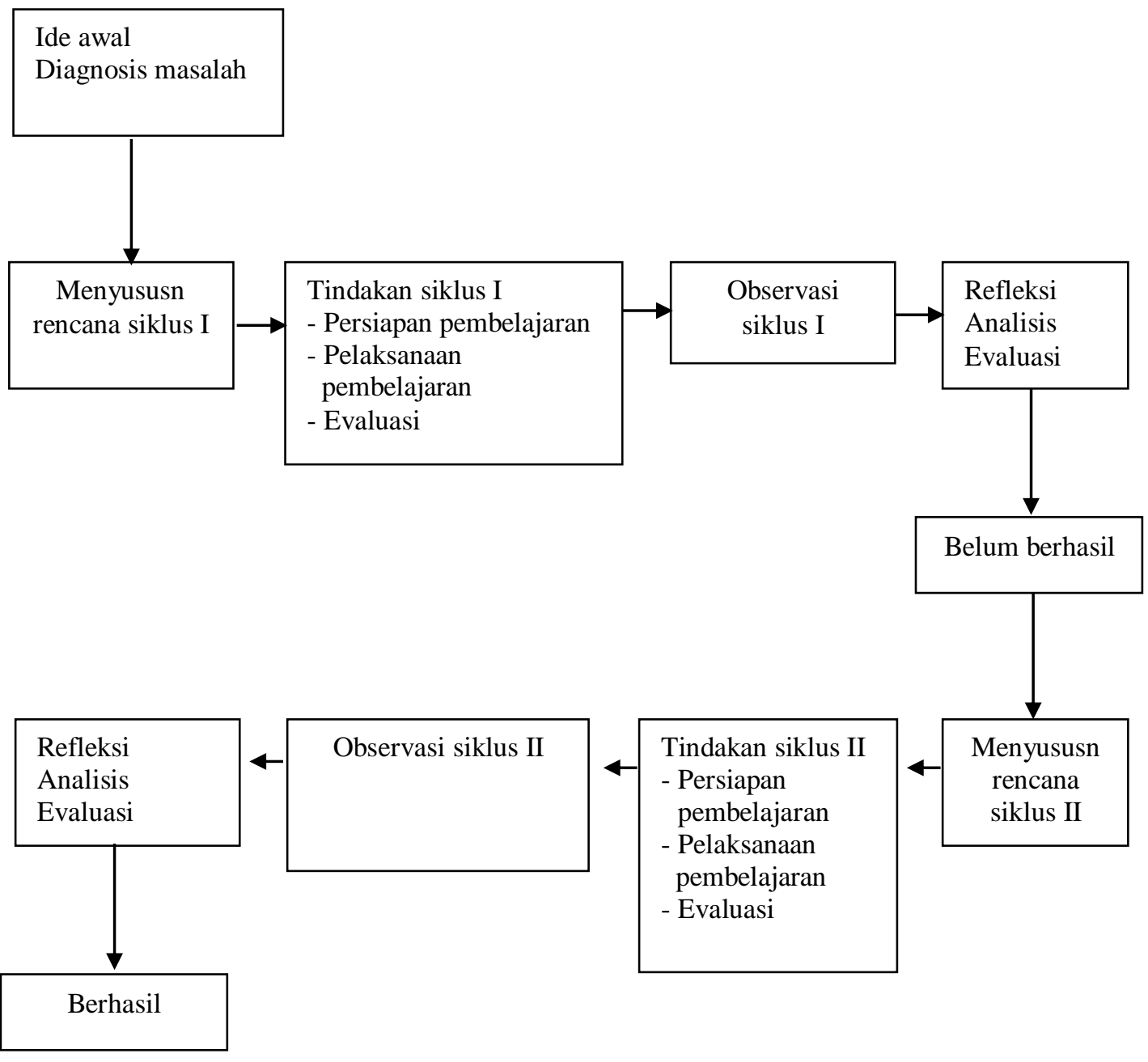

Gambar 3.1 Adaptasi Siklus Tindakan Kelas Mc Taggart (1988)

I. Indikator Kinerja

Indikator keberhasilan dalam penelitian ini meliputi indikator proses dan hasil dalam penerapan gambar luas daerah sebagai media pembelajaran. Dari segi proses ditandai oleh keaktifan siswa dalam proses pembelajaran. Terlaksananya pembelajaran sesuai dengan rencana pada tahap-tahap pembelajaran dicapai dengan menggunakan gambar luas daerah sebagai media pembelajaran.

Hipotesis tindakan dalam penelitian ini adalah penggunaan gambar luas daerah sebagai media dapat menjadi salah saru alternatif solusi yang tepat untuk meningkatkan pemahaman siswa memahami konsep operasi penjumalah bilangan pecahan di kelas VI SD Negeri 60
Pongka. Adapun kriteria yang digunakan untuk mengetahui kemampuan siswa adalah sesuai dengan kriteria sukses yang digunakan minimal 6,5 nilai hasil yang di peroleh setiap siswa. Berdasarkan kriteria standar tersebut, maka penulis menentukan tingkat kriteria keberhasilan dalam penelitian ini dari kemampuan siswa memahami penjumlahan bilangan pecahan.

\section{HASIL DAN PEMBAHASAN Hasil Penelitian}

Berdasarkan hasil tes awal diperoleh informasi bahwa subyek penelitian dapat menjawab soal no 1,2 , sedangkan untuk 3,4,5 masih melakukan kesalahan yaitu pada pola menentukan lambang bilangan yang diarsir. Subyek penelitian hanya sebagian menjawab 
soal no 1 dan 2 dengan benar. Sedangkan untuk soal no 3,4,5 masih melakukan kesalahan dalam menjawab soal. Setiap bagian masih terdapat kesalahan.untuk mengetahui alasan jawaban yang belum dipahami subyek penelitian, maka dilakukan wawancara. Berdasarkan tes awal dan wawancara, disimpulkan bahwa masih dirasa perlu meningkatkan pemahaman siswa operasi penjumlahan pecahan.

Dalam pelaksanaan tindakan pembelajaran, dengan menggunakan gambar sebagai media peneliti bertindak sebagai guru. Tahap-tahap pembelajaran setiap tindakan yaitu penanaman konsep pecahan, pecahan senilai, dan penjumlahan pecahan.

\section{Deskripsi siklus 1}

Materi pembelajaran yang dilaksanakan pada siklus 1 adalah penjumlahan pecahan biasa berpenyebut tidak sama yang masing-masing pembilangnya I. Pada awal pembelajaran siswa diingatkan kembali tentang macam-macam pecahan dalam bentuk luas daerah yang diarsir, menentukan KPK dari dua bilangan dan menentukan pecahan senilai. Pembelajaran tindakan dilaksanakan dalam satu kali pertemuan dengan alokasi waktu $2 \times 35$ menit

Indikator pembelajaran adalah siswa mampu melakukan penjumlahan, pengurangan, perkalian, dan pembagian pecahan. Sedangkan tujuan pembelajaran, (1) siswa dapat menentukan langkah-langkah untuk menyelesaikan soal-soal penjumlahan pecahan biasa berpenyebut tidak sama dan salah satu penyebutnya merupakan kelipatan penyebut yang lain serta masing-masing pembilangnya, (2) dapat menentukan langkah-langkah untuk menyelesaikan soal-soal penjumlahan pecahan biasa berpenyebut sama dan tidak sama dan penyebutnya bukan kelipatan penyebut yang lain serta masing-masing pembilangnya 1 .

Evaluasi yang diberikan adalah memberikan tes secara tertulis tentang penjumlahan pecahan biasa berpenyebut tidak sama dengan menggunakan bagian daerah yang diarsir pada persegi panjang, segitiga, dan lingkaran.
Pelaksanaan pembelajaran ini memerlukan alat peraga. Untuk itu peneliti menyiapkan karton berbentuk persegi panjang, segitiga, dan lingkaran dengan daerah yang diarsir pada luasan daerah. Sebelum peragaan dilakukan guru, terlebih dahulu guru mempresentasekan di kelas.

Sesuai dengan tahapan pelaksanaan pembelajaran dengan mengunakan gambar sebagai media, pelaksanaan tindakan dimulai dengan penyajian materi penjumlahan pecahan biasa berpenyebut tidak sama yang masingmasing pembilangnya 1 dengan menggunakan luas daerah bagian, yang dilakukan secara klasikal. Dalam kegiatan penyajian materi ini, peneliti bertindak sebagai guru. Selama pelaksanaan materi, guru mata pelajaran matematika dan teman sejawat mengamati jalannya pembelajaran materi yang disajikan adalah penjumlahan pecahan biasa berpenyebut tidak sama yang masing- masing pembilangnya 1 dengan mengunakan alat peraga dari kertas karton berbentuk persegi panjang, segitiga dan lingkaran. Kedua pengamat melaksanakan tugas pengamatan sesuai lembar pengamatan dan alat peraga dari karton terdiri dari dua warna yaitu hitam dan putih yang berbentuk persegi panjang, segitiga, dan lingkaran

\section{a. Pelaksanaan Tindakan siklus I}

Pembelajaran untuk tindakan I berlangsung selama 70 menit. Dalam pelaksanaan tindakan, peneliti bertindak sebagai guru. Mengawali tindakan pembelajaran ini peneliti mengucapkan salam kemudian menyampaikan topik yang akan dipelajari yaitu penjumlahan bilangan pecahan dengan menggunakan gambar luas daerah bagian dari suatu daerah luasan yang berbentuk persegi panjang, segitiga dan lingkaran setelah itu peneliti menyampaikan tujuan yang ingin dicapai.

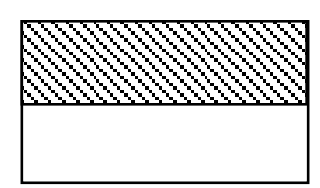

Gambar 1a. $\frac{1}{2}$ 


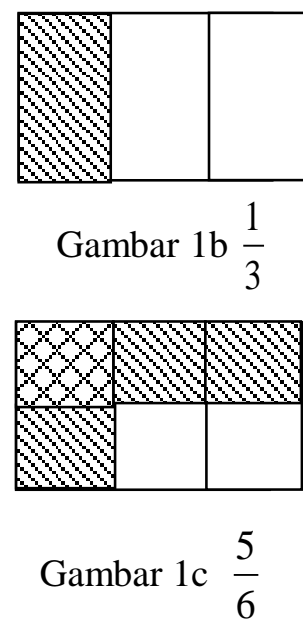

Untuk menghitung jumlah kedua pecahan diatas (siswa menggabungkan kedua gambar, luasan yang sama dengan pecahan setengah dan sepertiga maka yang cocok perenaman), kita letakan karton perenaman dibawah gambar 1c seperti terlihat pada gambar 1d (lihat gambar 1d)
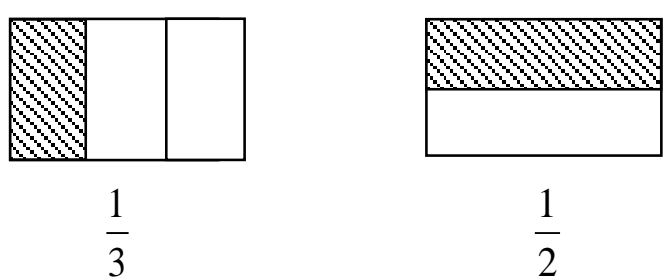

Gambar 1d

Pembelajaran memasuki kegiatan tahap selanjutnya yang merupakan kegiatan terpenting yaitu belajar kelompok. Sebelum memulai belajar, guru terlebih dahulu memberikan kesempatan kepada siswa untuk bersosialisasi dengan temannya. Kesempatan ini juga dimanfaatkan peneliti untuk mengetahui kemampuan setiap siswa. dari hasil pengamatan yang dilakukan terhadap siswa. Peneliti tidak menemukan pertentangan yang dapat cara belajar siswa terganggu.

Masalah yang dibahas dalam pembelajaran adalah pemahaman siswa terhadap penjumlahan pecahan., dengan materi pembelajaran penjumlahan pecahan biasa berpenyebut tidak sama yang masing-masing pembilangnya 1 dengan menggunakan daerah bagian dari suatu daerah luasan mengerjakan tugas LKS dan menggunakan kelengkapan yang sesuai dengan pecahan yang ditentukan.
Siswa bekerja dengan prosedur serta melengkapi kalimat yang ada pada soal yang di berikan guru dan akhirnya mereka dapat menentukan langkah-langkah untuk menyelesaikan soal penjumlahan pecahan biasa berpenyebut tidak sama yang masing-masing pembilangnya 1 .

Kegiatan pembelajaran berlangsung lebih kurang 30 menit. Selama kegiatan, peneliti mengamati, mendengarkan, dan mencatat semua aktifitas yang dilakukan subyek penelitian selama pembelajaran berlangsung .setelah proses pembelajaran selesai, peneliti melanjutkan dengan wawancara dengan subyek penelitian. Anlisis wawancara dengan subyek penelitian terangkum sebagai berikut

1. Seluruh subyek peneliti menyatakan bahwa belajar dengan mengunakan gambar sebagai media pembelajaran lebih mereka sukai dibandng belajar dengan penjelasan atau ceramah. Alasan yang diberikan subyek penelitian yaitu mereka berkesempatan bertanya lebih banyak..

2. Sebagian subyek masih mengalami kesulitan dalam membagi daerah atas bagian yang sama besar karena jarang menggunakan penggaris dan tidak sungguh-sungguh juga sedikit hambatan disebabkan kurang teliti.

3. Siswa terlibat aktif dalam tugas selama belajar dan meneruskan tugas yang menjadi tanggung jawabnya.

4. Dalam mengambil giliran menjelaskan tugas, siswa bersedia menerima tugas dan mempunyai kepercayaan diri dalam menyelesaikan tugas-tugasnya.

5. Keinginan untuk mencapai kesuksesan siswa juga tampak, dimana antar siswa saling mengingatkan jika tidak ada siswa yang bersungguh- sungguh belajar.

6. Subyek bertanya pada guru bila ada hal hal yang tidak dimengerti.

b. Hasil Observasi Tindakan siklus 1

Pembelajaran tindakan siklus 1 diamati oleh dua orang pengamat yaitu seorang teman sejawat dari SD yang bersangkutan dan guru kelas VI sebagai guru matematika di SD Negeri 60 Pongka . Mereka melaporkan bahwa peneliti dalam pembelajaran tindakan 1 telah melaksanakan tugas sebagai berikut 
1. Peneliti menyampaikan materi yang dibahas dan menginformasikan indikator pembelajaran serta menjelaskan materi yang mendukung tugas yang akan diselesaikan siswa

2. Peneliti menggali pengetahuan yang dimiliki siswa sesuai dengan topik yang dibahas

3. Peneliti mengaitkan pelajaran dengan pengetahuan tes awal

4. Peneliti selalu membimbing siswa apabila ada siswa yang mengalami kesulitan dalam menyelesaikan soal penjumlahan pecahan yng telah di beriakan

5. Peneliti mendorong siswa agar meminta bantuan kepada teman kelompok sebelum meminta bantuan kepada guru

6. Peneliti meminta siswa membuat rangkuman materi pembelajaran penjumlahan pecahan dengan menggunkan daerah bagian yang di arsir terhadap kegiatan siswa peneliti melaporkan sebagai berikut:

7. Siswa dapat menentukan langkah-langkah untuk menyelesaikan soal penjumlahan pecahan biasa berpenyebut tidak sama yang masing-masing pembilangnya 1 dengan daerah bagian dari suatu luasan yang diarsir.

8. Siswa memberi respon senang yang merupakan hal yang baru terhadap proses pembelajaran, materi pembelajaran, cara belajar, cara guru mengajar serta suasana kelas yang menyenangkan

\section{c. Analisis dan Refleksi Tindakan Siklus 1}

Pembelajaran tindakan siklus 1 difokuskan pada penjumlahan pecahan biasa berpenyebut tidak sama dan masing-masing pembilangnya 1 dengan menggunakan daerah bagian dari suatu derah luasan. Pembelajaran dilaksanakan dengan menerapkan pembelajaran dengan menggunakan gambar luas daerah sebagai media. Untuk memperoleh data tentang pelaksanaan tindakan siklus1 dilakukan pengamatan, wawancara, tes, dan catatan lapangan. Hasil pengamatan, wawancara, tes dan catatan lapangan selama pelaksanaan tindakan dianalisis dan didiskusikan dengan pengamat sehingga diperoleh hal-hal sebagai berkut :
1. Penyajian pada tahap presentase untuk memperagakan penjumlahan pecahan biasa berpenyebut tidak sama dengan menggunakan daerah bagian dari suatu daerah luasan berjalan sebagaimaa yang telah direncanakan, namun untuk belajar dengan menggunakan gambar sebagai media disiapkan waktu yang cukup untuk kegiatan tersebut.

2. Siswa mengalami kesulitan dalam mengerjakan soal penjumlahan pecahan dengan alat peraga berupa karton yang berbentuk persegi panjang, segitiga, dan lingkaran. Kesulitan yang dialami siswa adalah belum memahami makna pecahan yang ada pada alat peraga yang diberikan.

3. Kerja kelompok siswa belum maksimal karena masih banyak siswa yang melakukan aktivitas lain pada saat diskusi kelompok.

4. Pembelajaran secara kelompok masih didominasi oleh siswa yang berkemampuan tinggi sehingga keaktifan siswa yang lain masih kurang.

5. Sebagian besar siswa masih ragu-ragu dalam mengemukakan ide atau pendapat bila ditanya oleh guru terkait dengan pembelajaran.

6. Masih banyak ditemukan siswa yang raguragu untuk menanyakan hal-hal yang dianggap belum jelas baginya.

Berdasarkan analisis dan refleksi pada tindakan siklus 1 dan mengacu pada kriteria sukses yang ditetapkan maka pembelajaran pada tindakan siklus 1 belum berhasil, dimana berdasarkan hasil tes masih ditemukan siswa yang mencapai nilai kurang dari 6,5. hasil tes siswa dapat dilihat pada lampiran 15 .

\section{Deskripsi Data siklus II \\ a. Perencanaan Siklus II}

Hasil analisis dan refleksi pada tindakan siklus 1 , semua subyek penelitian secara umum sudah mencapai indikator pembelajaran namun yang diharapkan yaitu dapat menentukan langkah-langkah untuk menyelesaikan soalsoal penjumlahan pecahan biasa berpenyebut tidak sama yang masing-masing pembilangnya 1 dan yang salah satu penyebutnya merupakan kelipatan penyebut yang lain. bukan kelipatan 
salah satunya, dengan luas daerah bagian yang diarsir. Karena itu pembelajaran dilanjutkan dengan pembelajaran tindakan siklus II.

Pembelajaran tindakan siklus II diberikan agar dapat menentukan langkah-langkah untuk menyelesaikan soal-soal penjumlahan pecahan biasa berpenyebut tidak sama yang salah satu pembilangnya 1 dengan menggunakan gambar luas daerah yang diarsir. Pembelajaran tindakan siklus II dilaksanakan dalam satu kali pertemuan dengan alokasi waktu 2×30 menit. Indikator pembelajaran adalah siswa mampu melakukan pembelajaran, pengurangan, perkalian, dan pembagian pecahan, menentukan langkah-langkah untuk menyelesaikan soal-soal penjumlahan biasa berpenyebut tidak sama dan salah satu penyebutnya merupakan penyebut yang lain serta salah satu pembilangnya 1 serta menentukan langkah-langkah untuk menyelesaikan soal-soal penjumlahan pecahan biasa berpenyebut tidak sama dan penyebutnya bukan kelipatan salah satunya.

\section{b. Pelaksanaan Siklus II}

Sebelum kegiatan inti dalam pembelajaran, peneliti memulai dengan kegiatan awal yaitu memotivasi siswa dengan menunjukkan beberapa pecahan yang berbeda-beda dalam bentuk luasan daerah kemudian siswa diberi pertanyaan bagaimana menjumlahkan pecahan tersebut (pecahan biasa berpenyebut tidak sama) secara tepat dan seorang siswa diminta untuk menjawabnya. Untuk melacak pemahaman siswa, peneliti juga meminta siswa menentukan KPK dua bilangan dan pecahan senilai. Kegiatan ini dilakukan dengan cara tanya jawab.

Memasuki tahap kegiatan pembelajaran dengan menggunakan gambar luas daerah sebagai media pembelajaran dengan materi pembelajaran penjumlahan pecahan biasa, kelengkapan yang telah disediakan yaitu kertas karton warna hitam putih dan siswa akan berkerja sesuai dengan prosedur untuk menyelesaikan soal penjumalahn pecahan dengan menggunakan gambar luas derah arsiran, hal ini dikarenakan siswa dapat melihat langsung model dan luas daerah yang mewakili pecahan secara nyata.
Berdasarkan kegiatan siswa dalam menyelesaikan tugas-tugas yang diberikan peneliti dapat dianalisis beberapa hal sebagai berikut :

1. Dalam kelompok terjadi pembagi kerja masing-masing siswa memberi kesemptan keapada teman-teman satu kelompoknya untuk membagi gambar.

2. Untuk memperoleh hasil penjumlahan pecahan berdasarkan kegiatan yang telah dilakukan, msing-masing mencoba menjawab dengan menggabungkan gambar dari daerah luasan yang di arsir, kemudian saling mencocokan jawaban, jadi semua siswa tidak mengalami kesulitan dalam menyelesaikan tugasnya.

3. Siswa merasa tidak terbebani selama belajar dan kelihatan menikmati pekerjaannya meskipun keseriusan belajar tetap diperlihatkan selama belajar.

4. Keinginan untuk mencapai kesuksesan setiap siswa juga nampak, dimana antar anggota saling mengingatkan jika ada anggota kelompok yang tidak serius belajar.

Untuk memastikan hasil yang diperoleh dari kegiatan belajar dengan menggunakan gambar luas daerah sebagai media pembelajaran kali ini, selanjutnya guru mengadakan tanya jawab untuk mengetahui pemahaman siswa terhadap materi penjumlahan pecahan dengan menggunakan luas daerah.

Berdasarkan hasil tes yang diperoleh seluruh subyek penelitian mendapat skor yang sempurna yaitu masing-masing skornya ratarata minimal 7,0. Skor hasil tes tindakan siklus II dapat dilihat pada lampiran 17.

\section{c. Hasil Observasi Siklus II}

Seperti halnya pada pembelajaran tindakan siklus I, pembelajaran tindakan siklus II diamati oleh dua orang pengamat yaitu seorang teman sejawat dari guru sekolah yang bersangkutan kemudian guru kelas VI sebagai guru matematika kelas VI SD Negeri 60 Pongka melaporkan bahwa penelitian dalam pembelajaran tindakan II telah melaksanakan kegiatan sebagai berikut:

1) Peneliti menyampaikan materi yang akan dibahas dan menginformasikan tujuan pembelajaran serta menjelaskan materi 
yang mendukung tugas yang akan diselesaikan dalam kelompok

2) Peneliti memunculkan rasa ingin tahu/motivasi siswa.

3) Peneliti menggali pengetahuan prasyarat yang dimiliki siswa dengan topik yang dibahas tentang materi penjumlahan pecahan

4) Peneliti memberikan langkah-langkah penyelesaian pembelajaran penjunlahan pecahan dengan menggunakan luas daerah yang dilengkapi dengan alat peraga yang telah disediakan oleh peneliti.

d. Analisis dan Refleksi siklus II

Pembelajaran tindakan siklus II difokuskan pada penjumlahan pecahan biasa dengan menggunakan luasan daerah yang diarsir. Pembelajaran pada tindakan siklus II ini juga menerapkan belajar klasikal dan untuk memperoleh data tentang pelaksanaan tindakan siklus II dilakukan pengamatan, wawancara, tes, dan catatan lapangan. Selama pelaksanan tindakan dianalisis dan didiskusikan dengan pengamat diperoleh hal-hal sebagai berikut

1. Penyajian pada tahap presentasi untuk meragakan langkah-langkah menyelesaikan soal untuk penjumlahan pecahan biasa dengan menggunakan gambar luas daerah berlangsung sesuai rencana.

2. Siswa merasa senang mengerjakan soal penjumlahan pecahan dengan alat peraga berupa karton berbentuk persegi panjng, segitiga dan lingkaran yang disediakan

3. Siswa tidak mengalami kesulitan membagi bagian yang sama besar setelah diberi bimbingan seperlunyaoleh peneliti. Akhirnya siswa dapat mengerjakan sendiri

4. Siswa dapat menentukan langkah-langkah menyelesaikan soal untuk memperoleh hasil penjumlahan pecahan dengan menggunakan gambar luas daerah

5. Hasil tes tindakan siklus II menunjukan kemajuan, semua subyek penelitian memperoleh skor sesuai dengan yang diharapkan.

Berdasarkan hasil analisis dan refleksi dan mengacu pada kriteria sukses yang ditetapkan maka pembelajaran telah selesai. Dimana siswa telah memiliki pemahaman tentang penjumlahan pecahan dengan nilai rata-rata 7,5 .

\section{B. Pembahasan}

Hasil penelitian terhadap aktifitas dan hasil belajar dengan menggunakan gambar luas daerah, melalui tiga tahapan yaitu, konsep pacahan, pecahan senilai, dan penjumlahan pecahan. Pada siklus pertama tindakan siklus I dan tindakan siklus II mengalami peningkatan yang signifikan.

Hasil tindakan siklus I pertama belum mencapai hasil yang diharapkan karena sebagian subyek belum memahami pecahan, yang terdiri dari menentukan KPK, pecahan senilai, dan penjumlahan pecahan. pada tahap pertama menggunakan gambar luas daerah dalam penjumlahan pecahan siswa belum dapat menentukan lambang bilangan pecahan daerah yang diarsir, Namun siswa aktif dalam pembelajaran dan menyadari pentingnya memahami operasi penjumlahan pecahan. Hal ini terbukti bahwa siswa sudah memahami penjumlahan pecahan yang luas, akan menghasilkan pengetahuan yang berarti dalam kehidupan sehari-hari.

Keberhasilan tindakan siklus II mencapai kualifikasi yang sangat baik karena pada kegiatan yang terakhir dalam penjumlahan pecahan siswa mampu menjumlahkan pecahan dengan menggunakan gambar luas daerah arsiran. Hal ini menunjukan bahwa siswa telah memahami makna model dan luas daerah arsiran pada pecahan, sejalan dengan penjelasan dan prediksi (Herawati,1994: 94) bahwa dalam pembelajaran matematika utamanya pada jenjang sekolah dasar sangat diperlukan suatu teknik yang tepat agar konsep matematika yang diajarkan dapat dipahami dengan baik oleh siswa. Salah satu teknik yang digunakan adalah penggunaan gambar luas daerah sebagai media pembelajaran untuk menjelaskan suatu konsep khususnya penjumlahan bilangan pecahan, serta bertujuan untuk mengurangi tingkat abstraksi siswa Soejadi (Herawati,1994:15)

Keberhasilan siklus dari tindakan-tindakan karena siswa telah memahami konsep penjumlahan pecahan, yaitu menentukan 
lambang bilangan pecahan, kelipatan persekutuan terkecil (KPK) dan pecahan senilai. Langkah-langkah mempergunakan konsep pecahan meningkatkan pemahaman siswa terhadap operasi penjumlahan bilangan pecahan.

Keberhasilan PTK dari tindakan ketindakan karena siswa telah memahami tahap-tahap operasi penjumlahan bilangan pecahan yaitu pengembangan seluruh pada tahap penanaman konsep. Pada tahap ini siswa memahami nilai pecahan yang dijumlahkan, mengapa hasilnya begini atau begitu, apa manfaat dan tujuan penjumlahan dan bagaimana aplikasinya dalam kehidupan sehari-hari. Kemampuan siswa pada penjumlahan pecahan dengan menggunakam gambar luas daerah. Nampak bahwa pembelajaran belajar dengan menggunakan alat peraga luas daerah bangun persegi dapat meningktkan pemahaman siswa penjumlahan pecahan.

Pada siklus pertama dari tindakan I sampai tindakan ke siklus II PTK ini, siswa telah melakukan kegiatan operasi penjumlahan bilangan pecahan dengan kualifikasi sangat baik. Hal ini terlihat dari siswa telah memahami tahapan-tahapan ini yaitu tahap pemahaman dan penyempurnaan penjumlahan yang telah dihasilkan. Kegiatan penjumlahan pecahan adalah menjumlahkan bagian bagian dari suatu kesatuan yang utuh dibagi sama.

Keberhasilan tindakan pembelajaran dengan menggunakan gambar luas daerah pada penjumlahan pecahan dari tindakan ketindakan disebabkan oleh kemampuan siswa dalam memahami konsep penjumlahan pecahan yaitu pemahaman dan kesempurnaan jawaban sesuai dengan langkah-langkah penjumlahan pecahan sejalan dengan teori pembelajaran yang dilaksanakan.

Selain keberhasilan menggunakan gambar luas daerah sebagai media pembelajaran dalam PTK ini, juga disebabkan oleh adanya penggunaan alat peraga dalam pembelajaran hal ini sejalan dengan Nur faida (Soewito,1992: 5) "siswa yang melihat langsung pengertian konsep-konsep dari suatu materi pada benda-benda konkret yang sedang diperagakan dapat menimbulkan motifasi dan minat belajar siswa sekolah dasar.

\section{SIMPULAN DAN SARAN}

Proses pembelajaran dengan menggunakan gambar luas daerah dari aspek guru dan siswa dapat dicapai karena dari tindakan ketindakan refleksi dan perbaikan dengan melalui kolaborasi yang baik dengan pihak terkait dalam penelitian. Hasil belajar dengan menggunakan gambar luas daerah siswa kelas VI SD Negeri 60 Pongka telah mengalami peningkatan khususnya pada pembelajaran penjumlahan pecahan.

Sesuai dengan kesimpulan tersebut, maka dapat diajukan beberapa saran sebagai berikut: (1) Kepada guru SD agar menggunakan gambar luas daerah sebagai salah satu alternatif meningkatkan pemahman dan hasil belajar siswa dalam pembelajaran operasi penjumlahan bilangan pecahan. (2) Bagi peneliti selanjutnya, khususnya yang berkecimpung dalam pendidikan dasar, penelitian yang dilakukan dalam studi ini, hanya mengungkapkan salah satu alternative metode pembelajaran saja yang ada kaitannya dengan motivasi belajar, dan masih banyak lagi alternative-alternative lain yang belum diungkapkan dalam penelitian ini. Untuk itu disarankan bagi peneliti yang berminat untuk melakukan kajian lebih lanjut dan lebih mendalam.

\section{DAFTAR RUJUKAN}

Arsyad Azhar, 2004. Media Pembelajaran. Jakarta: PT Raja Grafindo Persada

Hartono P. 2003. Tahap-Tahap Perkembangan Kognitif Siswa: Depdiknas Jakarta

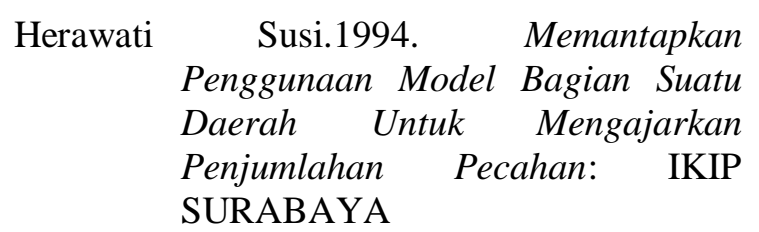

Hudoyo, Herman. 1990. Mengajar Beajar Matematika Usaha Nasional : Surabaya 
.................. 1996. Pengembangan Kurikulum Matematika dan Pelaksanaannya di Depan Kelas. Usaha Nasional: Suarabaya

Inganah S. 2003. Model Pembelajaran Segi Empat Dengan Pendekatan Realistik Pada Siswa Kelas II SLTP Negeri III Batu. Tesis Tidak Diterbitkan

Latri. 2003. Pembelajaran Volume Kubus dan Balok Secara Kontribusi Dengan Menggunakan Alat Peraga di Kelas VI SDN 10 Watampone. Proposal Tesis Tidak Diterbitkan

Miles, M.B dan Huberman. Analisis Data Kualitatif. Terjemahan oleh Tjeptjep Rohidi 1992 Jakarta UI Press

Moleong, L.J 1994 Metodologi Penelitian Kualitatif. Remajarosdakarya. Bandung

Muhsetio G. 2005. Pembelajaran Matematika di $S D$ : Universitas Terbuka

Ramadhoni,R. 1996. Anlisis Kemampuan

Menyelesaikan Kemampuan Operasi

Pecahan dalam Soal Cerita
Matematika. Skripsi. FPMIPA IKIP Ujung Pandang.

Roi Jokers. 1991. Mengajar dengan Sukses : Gresindo Jakarta

Rusiyan, Tabrani. 1989. Pendekatan Dalam Proses Belajar Mengajar : Remaja Karya Bandung

Susanto, 2007. Pengembangan KTSP Dengan Manajemen Visi. Jakarta

Soenarto Sunaryo. 2002. Interaksi Pembelajaran dan Pengelolaan Kelas. Depdiknas: Jakarta

Sukarman, Herry. 2002. Pengelolaan Proses Belajar Mengajar. Depdiknas.

Tiro, M Arif 1994. Cara Mengajar Konsep Pecahan di Sekolah Dasar "Transfprmasi" Vol. 11994. Ujung pandang.

Winkel, W.S. 1991. Psikologi Pengajaran. Remaja Karya: Bandung

Wiriaatmadja R, 2005. Metode Penelitian Tindakan Kelas. Remaja Rosda Karya: Bandung 